\title{
"Hungry for interpretation": Woyzeck on the Highveld and the polyphony of performance
}

\author{
Veronika Ambros and Lawrence Switzky
}

\begin{abstract}
"With hindsight, I can say that one of the things that puppets do well that humans beings don't is they exemplify the everyday struggle to live that we all experience privately. The puppeteer has to struggle to keep them alive every moment they are onstage. If the puppeteer's attention to this task fails, the puppet immediately 'dies.' The puppeteers' effort in mastering their mechanisms and willing them into living, emotionally charged beings becomes a kind of triumph."
\end{abstract}

Basil Jones in Handspring Puppet Company (2009)

Theatre has always been a crossroads for the arts. Prague School scholars, however, were among the first to conceptualize the audience's experience of the polyphony of media, accounting for classical as much as for modern theatre. Their "comparative exploration of arts" (ŠLAISOVÁ 2014) has been discussed in terms of intermediality, in the sense of "mutual influences between media" (KATTENBELT 2008). Multimediality, however, as the dynamic combination of media, poses different and complex methodological questions that the Prague School is also well equipped to address.

As a seminal work of multimedia performance, Handspring Puppet Theatre's Woyzeck on the Highveld brings semiotics into action by juxtaposing media in a unique way. It demands interpretative frameworks beyond the means usually available to puppet theatre and to multimedia performance considered in isolation from each other. Basil Jones, of Handspring Puppet Company, describes the willing to life of the puppet as a "kind of triumph." This is a triumph that the audience of Woyzeck on the Highveld also experiences, not only in sustaining puppet life, but also in coordinating that life with a structure and its elements. Based on the Prague School approach to man and objects and its comparatist approach to the arts, this essay traces the structure and elements of this specific production. In doing so, it provides a model for and invites a discussion about the analysis of contemporary multimedia and puppet performance. 


\section{Background}

Handspring Puppet Theatre's Woyzeck on the Highveld (first performed in 1992; revived in 2008), the first collaboration between William Kentridge, Basil Jones, and Adrian Kohler, confronts us with an interpretative challenge from the moment we hear about it: what is Heinrich Woyzeck, the anti-hero of Georg Büchner's 1836 play Woyzeck, doing in the middle of the South African landscape? The challenge continues as the performance begins. We anticipate a tragedy, but a fairground barker out of a German Moritat promises us, true to the genre, "a beautiful murder." We expect a puppet show, but we encounter a live actor with a megaphone followed by screen projections, what William Kentridge has called "stone age animation." When the puppets do arrive, they are not clearly located in any single specific puppetry tradition: they are not hand puppets, marionettes, or Bunraku, but rod puppets presented by two or more visible artists, often combinations of black and white and male and female performers. And these performers are not only operators who are meant to disappear behind their characters, but compassionate actors who perform for each other and their puppet-figures.

Woyzeck on the Highveld was first performed in 1992, one of the last years of apartheid in South Africa, although the production is set in the 1950s, the first full decade of apartheid as an official government policy in South Africa. The mix of racially marked performers would have been particularly controversial at these first presentations. (It may have escaped controversy because, its creators have speculated, it was understood as puppet theatre presumably made for children). As Kohler recalls, "We were very proud of the black/white mix in the cast. Not that it was unique. Non-racial theatre did exist in the early '90s, though there wasn't that much of it” (Personal Correspondence). Woyzeck opened a trilogy of performances based on classical texts of world dramatic literature that would include Goethe's Faust (Faustus in Africa, 1995) and Jarry's Ubu Roi (Ubu and the Truth Commission, 1997). In each case the original was transposed to Africa because, according to Kentridge, he speaks "in all of his works about his land, its beauty and sorrow" (KLETT 1995: 8).

In their discussions of Woyzeck on the Highveld and other performances, particularly their 2008 collaboration with the English National Theatre, War Horse, Handspring Puppet Company have mentioned that they think in semiotic terms during the creation of their work. Basil Jones, for example, notes that in War Horse, animals needed to communicate with spectators without the benefit of a spoken text and verbal semiotics:

[...] if I happen to be manipulating an animal and I'm not capable of using words, and I have to communicate with you, an audience member, you are hungrily interpreting and trying to make meaning of every tiny movement the puppet makes. [...] [In War Horse], we had to move into another form of text, namely the text of movement and of relationships, of hapticity. It's an area of semiotics that is not much written about, but it is really important to us. (KOHLER et al. 2014: 30) 


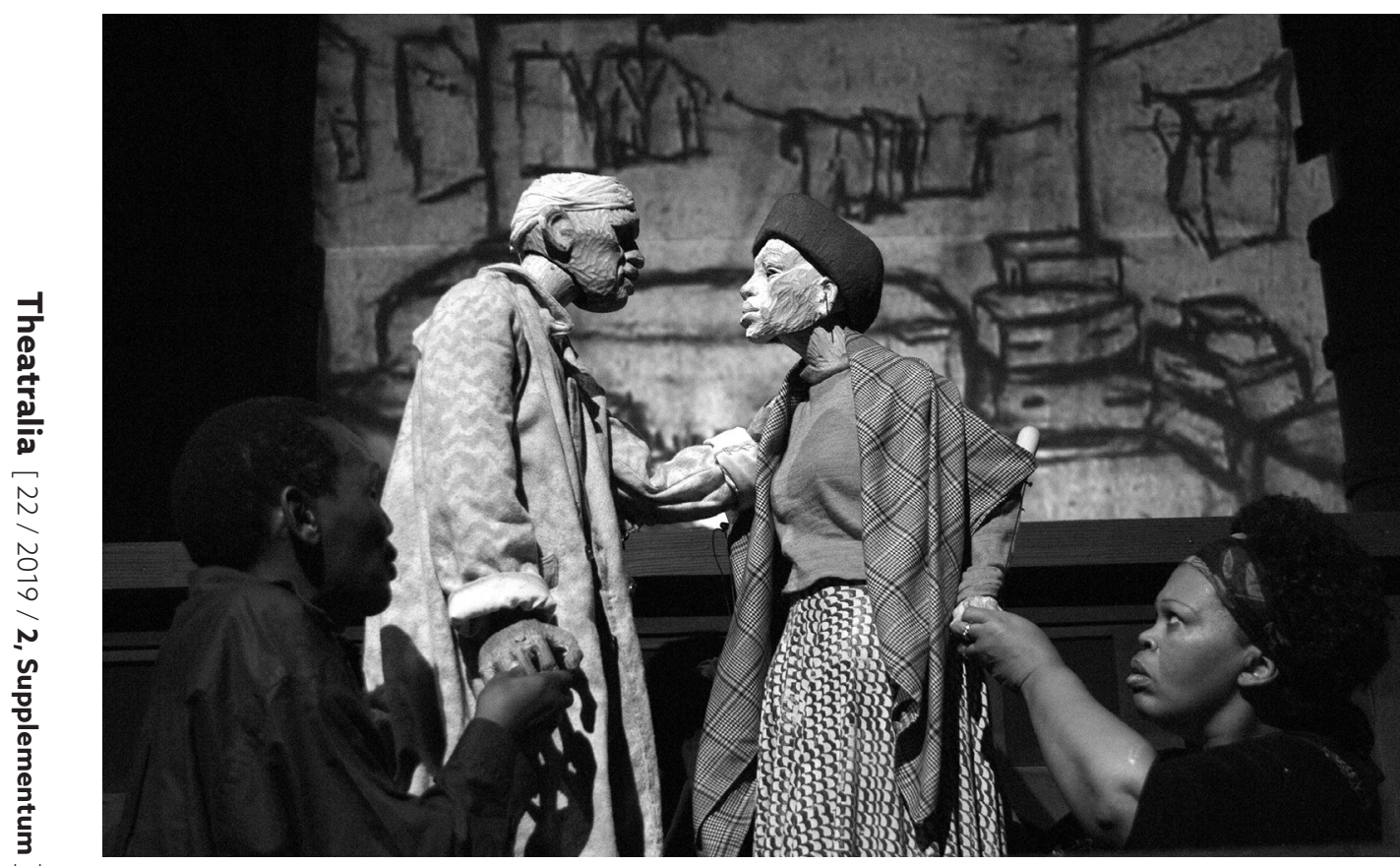

Fig. 1: Woyzeck on the Highveld, 2009, performance in Johannesburg, dir. Catherine Meyburgh from a stage production by William Kentridge, Handspring Puppet Company

The official history of the Handspring Puppet Company (TAYLOR 2009) refers several times to semiotics without specifying the particular brand they have in mind. It does, however, refer to the puppeteer's "struggle to keep [the puppets] alive" (one instance is cited in the epigraph to this essay), a task that is distributed to the audience through its perceptual and hermeneutic activities. In this volume of Theatralia in which the Prague School is applied to various historical and contemporary performances, an analysis of Woyzeck on the Highveld through the ideas of Prague School semiotics will extend Handspring's inquiry into the reception of their complex multimedia artworks and the prominent concern with co-creating puppet life. We contend that like the audiences of War Horse, spectators of Handspring's Woyzeck, in which the title character is often treated like and compared to animals and inanimate objects, and in which speech does not function according to dialogic norms, are also "hungrily interpreting and trying to make meaning." Prague School semiotics can uniquely illuminate the challenges and delights of hungry interpretation in this landmark of modern puppet theater.

Even before the Prague Linguistic Circle (Pražský lingvistický kroužek = PLK) was founded in 1926, theater and literary scholars Jan Mukařovský, Petr Bogatyrev and Otakar Zich published studies on puppetry (coincidentally all in 1923). In subsequent essays, Prague School theorists laid the foundations for the study of puppet theatre throughout the twentieth and twenty-first centuries. Jiří Veltruský presented the relation between man and object as a dynamic aesthetic concept and authored several subsequent studies of puppets while Mukařovský, Jindřich Honzl and Roman 
Jakobson also paid attention to gestures, postures and statues on stage. They all absorbed and developed each other's ideas, conceptualizing their contemporary culture together.

In addition, the PLK was uniquely equipped to theorize the polyphony, ambiguity, and semantic as well as discursive shifts of experimental performances at large through concepts such as the "stage figure" or "actor's figure" (as opposed to the "characters" readers encounter in fiction); forms of discourse and stage speech, such as dialogue and monologue; the presentation of space and time; the theatrical tradition that undergirds and suffuses a production; reception (referred to as concretization by Felix Vodička in MATEJKA and POMORSKA 1978); and the historical and semantic contexts of a performance. The Prague School theory of theater was, according to Veltruský, a "common effort" that led to a keen study of radically different forms of theater, such as the avant-garde of the first three decades of the 20th century and classical Chinese theater (VELTRUSKÝ 1987: 141). The benefit of the Prague School approach was that the scholars collaborated with artists, basing their semiotic analysis on experimental staging, texts and acting. Director E. F. Burian's 1940 stage adaptation of The Ratcatcher (Krysař), a story by Viktor Dyk, inspired a seminal study of dialogue and monologue by Mukařovský.

Roman Jakobson analyzed the performance of the Liberated Theatre (19261938), a popular stage troupe, by examining their use of language and ways of creating fun. Jakobson proposed an approach applicable to modern theater's linguistic games. Veltruský and Karel Brušák explored the role of space on stage. Brušák's study of Chinese theater, like Bogatyrev's analysis of folk theater, expanded the conventional categories of theater analysis. Their theories enriched the work of contemporary artists and their successors. These included director Alfred Radok and set designer Josef Svoboda, whose highly acclaimed performances with Magic Lantern/Laterna Magica combining live action with film projections (polyekran) and music have dazzled international audiences ever since their inception. Like Kentridge and Erwin Piscator, Radok's performances were less adaptations than autonomous works of art no matter whether they were presenting a well-known text or braiding it with images and music (as in Bohumil Martinu's Opening of the Wells, Alfréd Radok's banned performance in Laterna Magica in 1960 and 1966).

\section{The shift of the dominant: from romantic drama to multimedia puppet theatre}

“... the artistic construction of today's scenic work [has become] a protean process which consists in a constant regrouping of components, in an agitated replacing of the dominant one, in an obliteration of the boundaries between drama and kindred forms (the revue, the dance, acrobatics, etc.).” (MUKAǨOVSKÝ 1977a: 112-113) 
The PLK concept of the dominant can help to understand the transposition of Woyzeck from a play with actors, located in Romantic and proto-expressionist traditions, to a play with puppets and animated images. Described perhaps most elegantly by Mukařovský in "Attempt at a Structural Analysis" as a "complex hierarchy that is unified," we can speak about the dominant of a work of art, i.e. "the prevalence of one component over others" (MUKAǨKOVSKÝ 1977: 192). Furthermore, as Mukařovský noted elsewhere, "If the background tradition shifts, the structure changes as well as the dominant and the work acquires a totally new appearance" (MUKAŘOVSKÝ 1932). In the case of Woyzeck on the Highveld, we are dealing not only with the maneuvers of adaptation - such as "repetition without replication" and "transcoding" (HUTCHEON 2012) - but with translation into a different "system of values" and "hierarchy of values" (MUKAǨOVSKÝ 1977) that attend the history of multimedia theatre and puppet theatre. The title, Woyzeck on the Highveld, likewise points to a shift toward a particular South African landscape as a new set of signs.

Büchner's Woyzeck has been revived and restaged countless times since Max Reinhardt first produced it for the theatre in 1913 (including as an opera in the 1920s by Alban Berg, which Kentridge has also recently directed). But the shift from a theatre of actors to a theatre of puppets has a decisive influence on the structure of the play as well as how we understand its lineage - the traditions and aesthetic ideas that, according to theatre historian Marvin Carlson, "ghost" any performance of a play (CARLSON 2001).

Although Georg Büchner wrote after the Napoleonic Wars, at a time of great interest in the mechanical, he did not compose Woyzeck for puppets. The collaboration between Kentridge and Handspring aligned Woyzeck with different theatrical genres, such as Japanese and Czech puppet performance, that had not traditionally been part of the discursive history of the play. In fact, Kentridge claims that he has deliberately refused to engage with the stage history of Woyzeck. "Not knowing the tradition of performances of Woyzeck" has made it easier "to take liberties and make discoveries with the text that surprised people who knew it very well" (KENTRIDGE 2016).

Hence, we too set questions of adaptation and fidelity aside, and examine the "discoveries" inherent in the performance of Woyzeck on the Highveld. By shifting the background tradition of the play from solely human performers to a mix of human and puppet actors, we are enabled to pay attention to the discrete choices of this staging, including its title, the reduced number of characters and their professional backgrounds as well as the individual episodes. As Bogatyrev suggests, "It is particularly useful to analyze theatrical signs and their perception by the audience on the basis of material provided by puppet theater" (BOGATYREV 1982: 57). In Woyzeck on the Highveld the mix of live and inanimate actors, animated film projection, and music present various semantic shifts. They inform us about the echo of an incomplete text concretized, and as Felix Vodička observed, "A new concretization always entails a regeneration of the work" (VODIČKA 1982: 128).

With Reinhardt, Woyzeck was placed in the new historical context of German art in the early twentieth century (particularly German Expressionism), a time that William Kentridge has long incorporated into his poetics. These shifts include the impression 


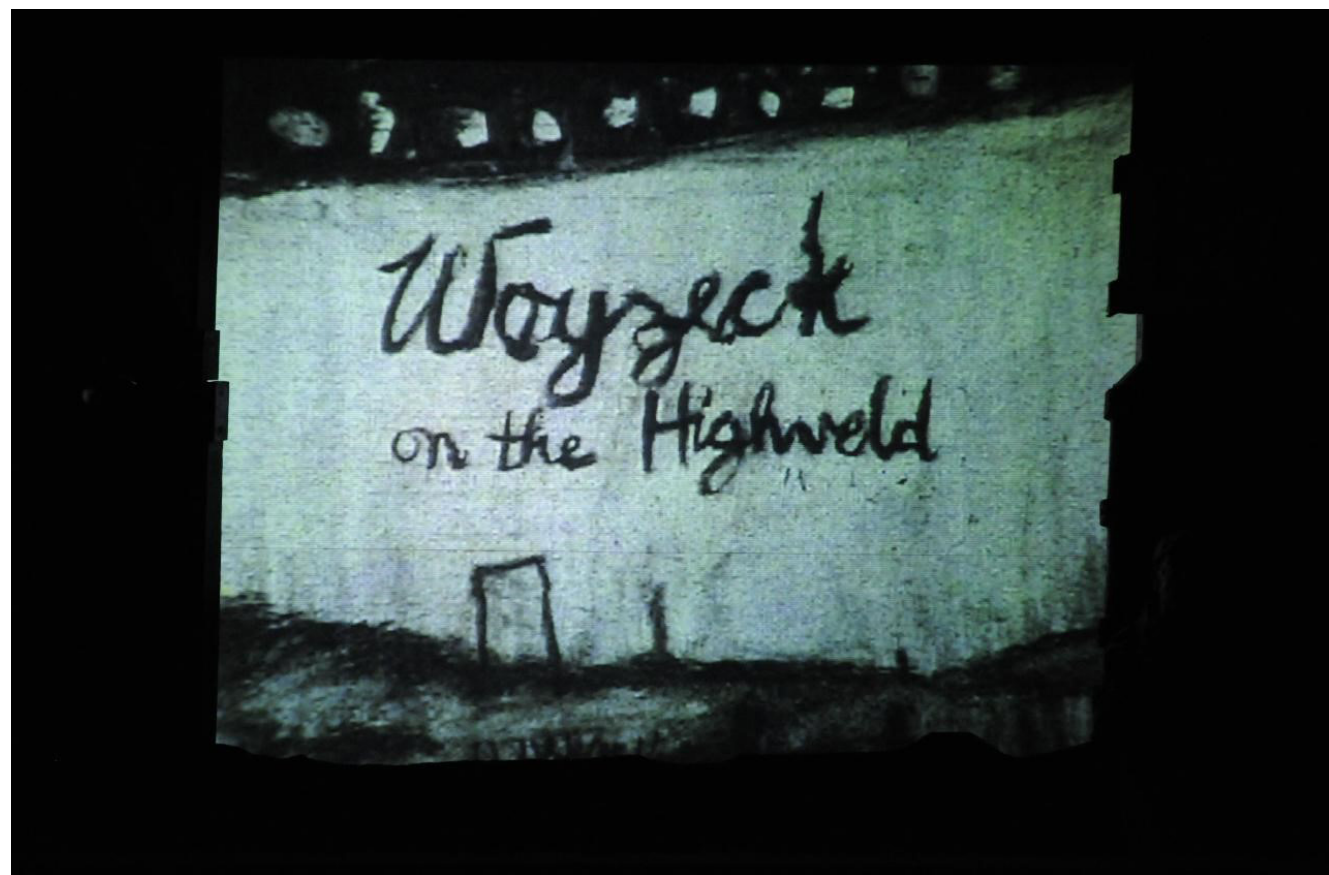

Fig. 2: Woyzeck on the Highveld, 2009, performance in Johannesburg, dir. Catherine Meyburgh from a stage production by William Kentridge, Handspring Puppet Company

of the World War I experience as captured in Karl Kraus' groundbreaking 1922 closet drama Die Letzten Tage der Menschheit (The Last Days of Mankind) that remained a dramatic text for most of the twentieth century. The haunting images of this time were transformed into the multimedia political theatre of Erwin Piscator, a predecessor of Kentridge, who also used the collaboration between different artists, puppetry, animated film, the simultaneity of performed actions and projected cartoons in his works. Piscator's techniques are echoed in Woyzeck on the Highveld in Kentridge's use of polyvisuality and different means of narration. Kentridge's animated drawings evoke Georg Grosz's animated cartoons and cut-out figures in Piscator's The Adventures of the Good Soldier Schwejk (Die Abenteuer des braven Soldaten Schwejk, 1927) in particular.

Piscator's stage version of Jaroslav Hašek's unfinished novel employed marionettes, which were intended to represent "the rigid types of old Austria's political and social life" (PISCATOR 1963: 190). Dadaist collage, in which the artist cuts up and glues together several images, inspired Piscator's staging as much as the structure of Hašek's great modernist novel, whereas Kentridge makes use of montage, the unification of diverse elements, in his production. And just as Kentridge places his projected images at the back of the stage, Piscator presented Grosz with "a huge drawing board at the back of the stage, on which [he] accompanied the action with his drawings (...)” (GROSZ 1973: n.p.). Unlike Piscator, however, Kentridge uses the projection screen in a mobile fashion, transforming the static image into a set, animated film or a moving backdrop. 


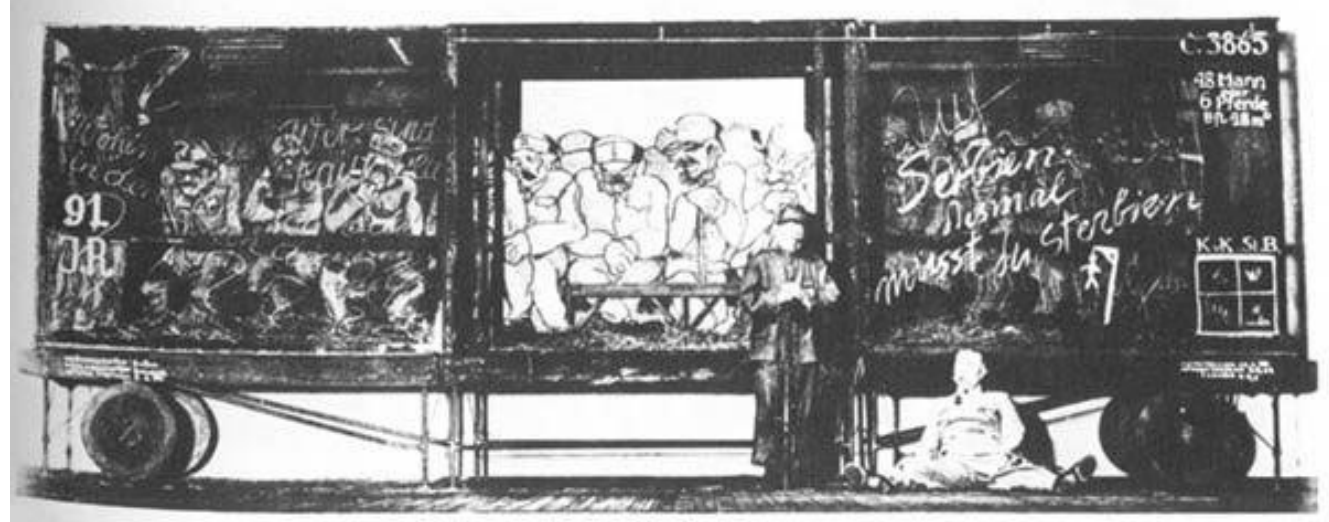

Fig. 3: Georg Grosz's animated cartoons and cut-out figures, The Adventures of the Good Soldier Schwejk (Die Abenteuer des braven Soldaten Schwejk, 1927), dir. Erwin Piscator.

The PLK concept of aktualizace also enables us to understand the performances in Woyzeck on the Highveld. Mukařovský writes about aktualizace, often translated as foregrounding, when a "work of art is a system of components aesthetically deautomatized and organized into a complete hierarchy that is unified by the prevalence of one component over the others" (MUKAŘOVSKÝ 1982: 171). Kentridge's images de-automatize the convention of the static backdrop as they move between film projections, animated actions and a three-dimensional set design, thus inviting the viewer to re-evaluate her/ his expectations. Kentridge's subsequent theatrical productions, as in Woyzeck, have investigted these intersections of two-dimensional and three-dimensional drawing. According to Kentridge, "In a theatre production, one explores the artifice of [the] stage door, a real door in a fake wall, tests its limits. That is the illusionism of a painted theatre flat with a working door inserted into it. Because our experiment [The Head and the Load, 2018] balanced between theatre and film, our door is even more fake than a stage door. It is a drawn version of a stage door (just a sheet of cardboard against a solid wall)." (KENTRIDGE and TAYLOR 2018: 10)

The barker who opens, closes, and narrates the production might remind us of another type of defamiliarization, i.e. the Brechtian singer who distances himself from his role (Verfremdung). He is the epitome of a different version of the phenomenon of defamiliarization. However, the positioning of the three-dimensional barker against Kentridge's two-dimensional curtain and the barker's various roles as a stagehand, as a puppeteer, and as a commentator foreground different and more playful theatrical traditions - in other words, he "actualizes" or "recycles" old techniques.

As Kentridge observes of the episodic structure of Woyzeck on the Highveld, "[this] makes it more filmic, more exciting and more contemporary" (WESTIN 2012). On the other hand, the Moritat (or "murder ballad") tradition - and the fairground barker who presents it to us - frames the production and fulfills many functions. He conjures the fairy tale tradition of something that did and did not happen (foregrounded by the 
barker's conclusion to his first scene, "The commencement of the beginning is about to start"). At the end, the barker reveals himself as a director, ordering the Doctor and the Captain offstage: "Get out!" He subverts the conventional association between puppets and theatre for children and restores the ancient tradition of marketplace puppet performances. He also links the fictional world with the actual world of the audience while the puppeteers are generally partially hidden. As the Greek chorus, the barker has direct contact with the audience, comments on the action, and evaluates and narrates parts of it. As the only definitely human actor, he evokes the folkloric tradition. Bogatyrev observed puppet theatre against the background of theater with live actors (BOGATYREV 1982: 62); in Woyzeck on the Highveld, the presence of the barker and the visibility of the puppeteers also brings "the tension between the two arts" to the fore (BOGATYREV 1982: 62). The barker, however, determines the entirety of the performance as popular entertainment confirmed by his promise of "a beautiful murder" that is appealing to the phenomenon of thrill (Angstlust, as Michael Balint called it), a strange blend of fear and enjoyment (BALINT 1994). The projected procession of infirm people upsets the barker's promise of the "beautiful murder" and the fear it conjures. Handspring uses, as Zich would have it, the creepy quality inherent in puppets. According to Zich "puppets may be either taken for live people, or as un-live puppets. Either we take puppets as puppets (i.e. we stress their un-live qualities and their materiality). In such a case, however, we cannot take equally seriously their speech and movements, in brief their 'manifestations of life'; we thus find them comical or grotesque" (ZICH 2015: 507). On the other hand, "the awareness of the factual un-liveness of puppets moves to the background and it is apparent merely as a sensation of something inexplicable, a certain mystery that raises a sense of amazement. In this case, puppets have an uncanny effect on us" (ZICH 2015: 507).

The opposite reaction described by Zich is elicited by the only animal puppet, a rhino who is put on display for his ability to follow orders to count and to pee, and appeals to the comic side of puppets. Like Woyzeck, he is also subject to drill by the authorities who try to control even his urinary functions. (As the doctor tells him, "I saw it, Woyzeck, you pissed on the street. You pissed against the wall like a dog.") The production draws a parallel between Woyzeck and the rhino and exposes the cruelty of people in the person of the exploitative barker causing the Gogolian laughter through tears.

Handspring's background also invokes the tradition of Japanese puppetry, particularly Bunraku and the Ningyō jōruri, the traditional Japanese puppet theatre that flourished in Osaka in the early seventeenth century through the verbally sophisticated and emotionally textured plays of Chikamatsu Monzaemon. In Woyzeck on the Highveld, the puppets have two operators, one of whom takes on the role of the "chanter" that is traditionally separated from the role of the puppeteers in Japanese puppet theatre. Handspring's puppets are likewise hybrids of the large puppets of the late sixteenth century, held above the head by a single performer, and the three-man puppets, held in front of the performers, later associated with Bunraku and Kabuki theatre. In addition to preserving the material forms of Japanese puppetry, Handspring's Woyzeck echoes the "love-suicide" genre, the most significant dramatic innovation of seven- 
teenth-century Ningyō jōruri. Woyzeck and Maria's march through the wilderness surrounding the post-industrial cityscape before Maria's murder recalls the michiyuki or "lovers' journey," a "typical feature of puppet plays (and, in briefer form, of Noh plays before them)" (KEENE 1998: 24). The michiyuki ornamentally describes features of the landscape and puns on the names of places passed by the lovers on their journey. In Woyzeck on the Highveld, the customary pastoral landscape of bridges and rivers is despoiled, while conventional encomia to the moon are transposed into a ghastly exchange: "Look how red the moon is!" "Like a bloody blade." They are part of many allusions to celestial spheres that are akin to PLK theorist Jindřich Honzl's discussion of Karl Bühler's deixis am Phantasma: "Poetic reference to something that does not transpire on stage we may call phantasma-oriented deixis, since it specifies a dramatic action that is realized solely in the spectator's imagination" (HONZL 2017: 124). Woyzeck on the Highveld ends with comments on the "beautiful murder," but in contrast to the conventions of the Japanese love-suicide genre the audience does not directly witness an aestheticized enactment of his death.

\section{Construction of semantic context}

To Jiří Veltruský, context unfolds as "a dynamic unit of meaning in the sense that its meaning emerges gradually in time so that when the context is completed all the units of which it is composed are present in the addressee's mind in the order in which they were uttered" (VELTRUSKÝ 1977: 36). Kentridge's images are, in this sense, various metonymies which create a semantic context simultaneous with the fragmented structure of the spoken text. The horseshoe, for instance, which reappears throughout the performance, might connote a lost object and the search for luck and more broadly the semantic field of superstition.

Likewise, a procession of the invalids as shadow puppets, which occurs at several junctures in the performance, evokes the social and economic inequality endemic to the 1950s mining community outside Johannesburg. At the same time, they substitute for the variety of characters in Büchner's play as it is usually performed, which contains several more named roles than the Handspring production.

The visual semantic context, especially Kentridge's images, sets the social and historical milieu and illuminates the state of Woyzeck's mind. German and South African folkloric traditions (in the latter case, township music in particular), popular music, and church music create the acoustic semantic context. The dialogue is accompanied by the haunting and repetitive music of Alfred Makgalemele, a singer Kentridge encountered on the streets of Johannesburg in the 1980s, which Woyzeck's friend Andres presents diegetically when he plays the accordion in the performance. According to Adrian Kohler, Makgalemele's music suggests several aspects of Black South African experience, particularly itinerancy, disability, and religiosity: "He grew up an orphan in Lesotho and had contracted polio at a young age and both his legs had withered. [...] The quality of his music that suited the Woyzeck production so well was the sound 


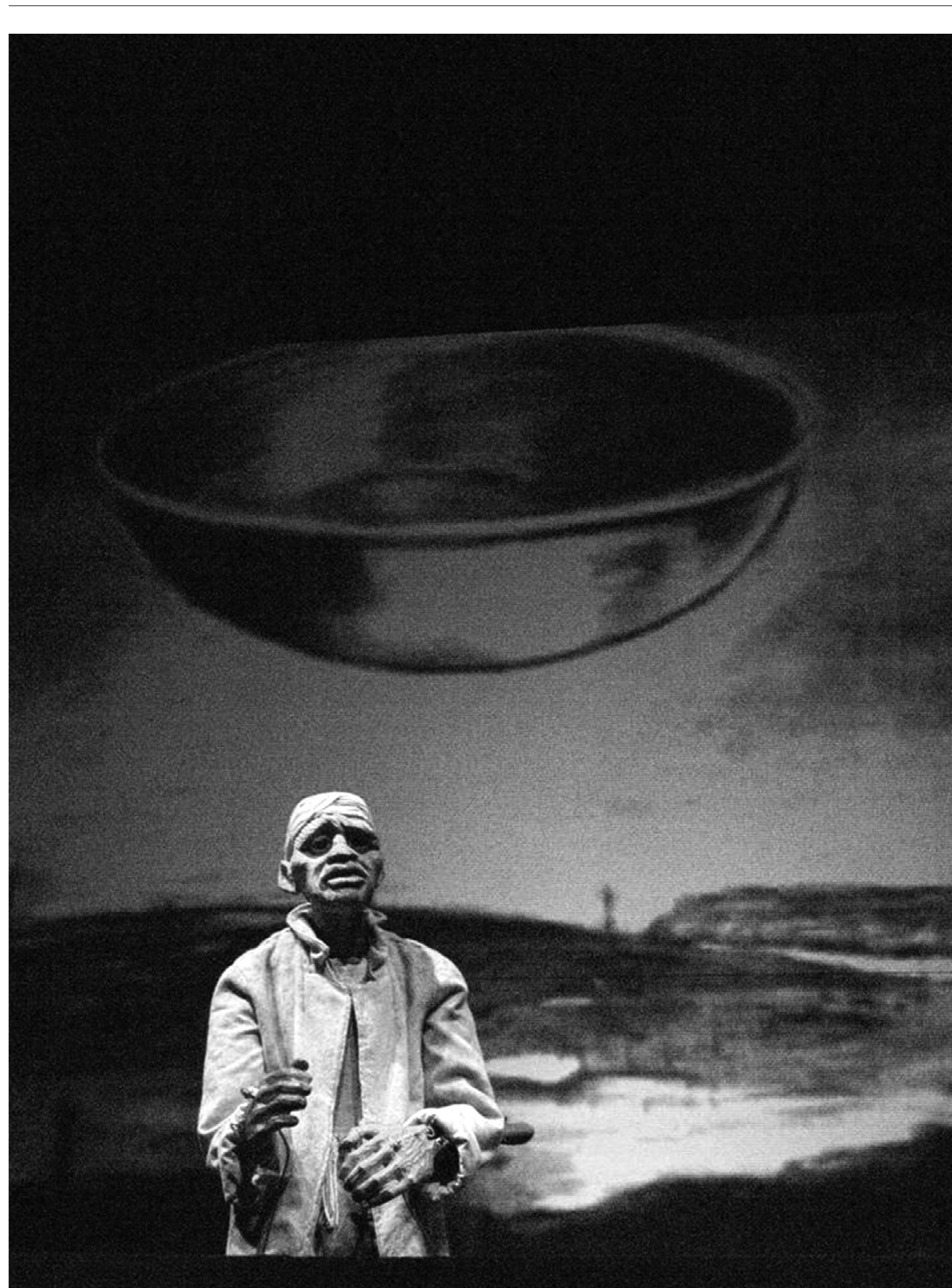

Fig. 4: Woyzeck on the Highveld, 2009, performance in Johannesburg, dir. Catherine Meyburgh from a stage production by William Kentridge, Handspring Puppet Company 


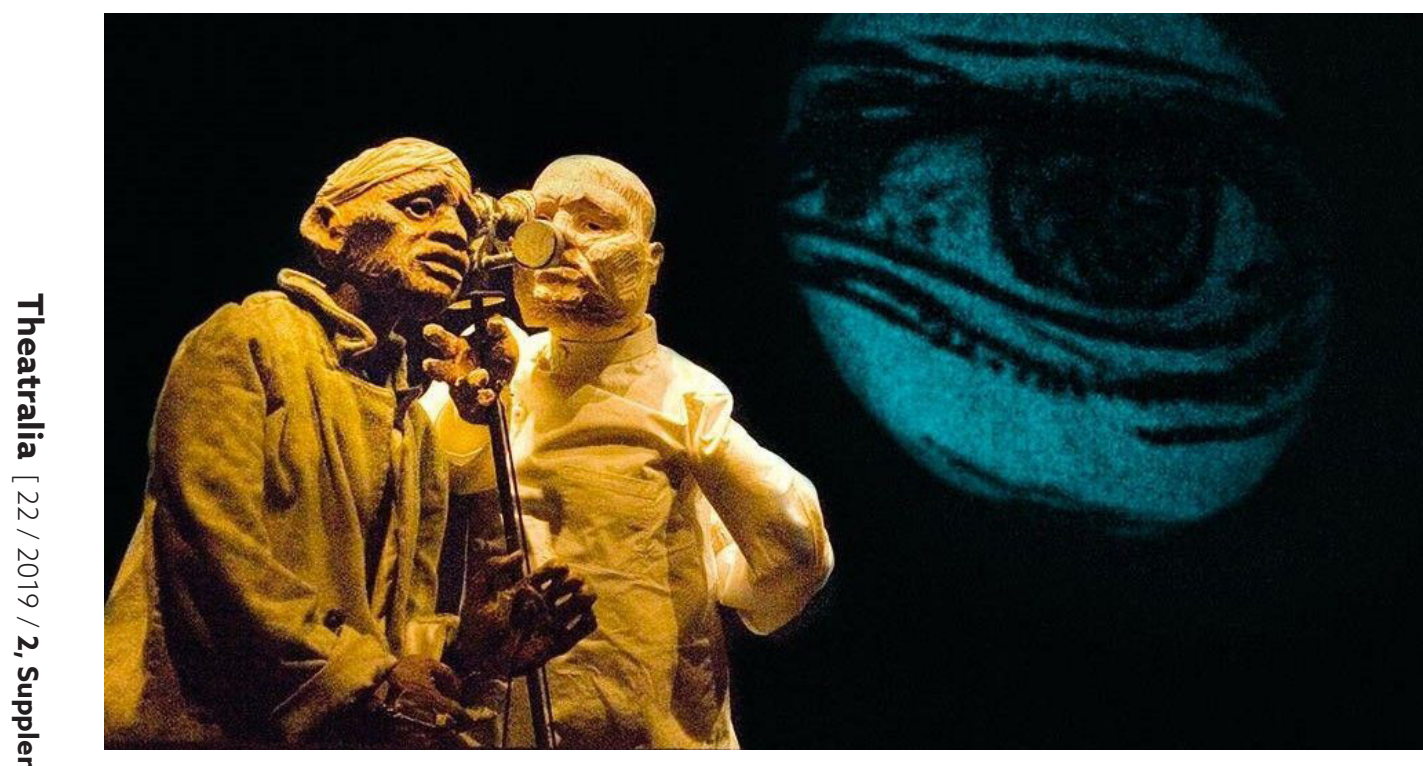

Fig. 5: Woyzeck on the Highveld, 2009, performance in Johannesburg, dir. Catherine Meyburgh from a stage production by William Kentridge, Handspring Puppet Company

of local church music but more importantly was the sound of his voice in his music" (KOHLER, Private Correspondence). The accordion also recalls popular German tunes. Throughout the production, when Maria and the miner dance to the music, separately and together, they too confirm the entertainment of the working class.

The visual and semantic context is not equally available to the working-class and upperclass characters. At one point, the Doctor and Woyzeck are marked by dissonances at both levels. During a medical examination, the Doctor inspects his own ears and eyes using his stethoscope and compares what Woyzeck hears and sees with his own tunes and images. It results in comic relief caused by the discrepancy between sounds and sights.

In addition, Kentridge's animations and static backdrops visually evoke national and socio-cultural milieux. However, the visual backdrop subverts any univocality of semantic context by conjuring oneiric, symbolic, spiritual, and cosmic associations. According to some critics, Kentridge's imagery is subject to "surrealist transformation - the plunger of Soho's infusion coffee maker turns into the bore of a mine shaft - to express their hazy messages." (O’SULLIVAN 2001). As independent as each image might appear, Jan Mukařovský's dictum applies here: "in a work of art, each of its components acquires its value only in its relationship to the whole" (MUKAŘOVSKÝ 1982: 38). For instance, the image of the cat, which appears during one of Woyzeck's visits to the Doctor, is part of his real and imaginary world and at the same time an expression of his confused perception of the world around him.

The music and images create a semantic context either confirmed or subverted by spoken (and sometimes written) language. They distance automatized associations and create new ones. Sometimes the relationship between them is contrapuntal, as in the 
second procession of invalids, when the hymn-like music, noted earlier, contradicts the imagery of poverty.

Some associations, expressed either verbally or in images, achieve a similar effect by contrasting actions and figments of imagination. They emerge in different contexts and evoke mundane or everyday objects (coffee pots, wrenches, shovels) or creatures (dogs and cats). Although they sometimes reveal the perceptual biases or inner psychology of specific characters, they are not yoked to any single character. In the highly original medical examination scene, the stethoscope turns into a device that externalizes the inner world of either subject by capturing their cacophony and harmony, visual and aural. When the doctor listens to his own body, he perceives orderly and "civilized" music and a domesticated cat. Woyzeck, however, produces an indigenous folk song, a series of submerged or overflowing objects, and an angry cat and dog.

\section{Language}

The discourse in Woyzeck on the Highveld consists of various patterns in terms of the typology of speech. There are orders, which are not exchanges; monologue and dialogue-like speeches; and instances of characters talking past each other (or, in one scene, smoking past each other). Some of the exchanges are close to what Jakobson and Mukařovský describe as "subjectless" discourse (MUKǍ̌OVSKÝ 1977b: 92) which often produce "comic effects." Subjectless discourse is achieved when the basic conditions of dialogue are missing, such as a common language, common topic, common context, and "the alternating relationship between 'I' and 'you'" (MUKAŘOVSKÝ 1977b: 87). Jakobson describes the effect of subjectless discourse as fun, another mode of aktualizace: "Fun in the theater interferes with the automatism of habit and teaches us anew how to touch, grasp, and evaluate a thing and a sign" (JAKOBSON 1987: 156). However, when the doctor and the captain poke fun at and reify Woyzeck, the audience laughs at their incomprehensible language, not at the dehumanization of their servant. Woyzeck's responses are also sometimes oblique, but not comedic.

The interrelation of the participants in a dialogue is therefore felt as a tension not bound to either of the two speaking persons but actually existing "between" them; it is thus objectified as the "psychological situation" (MUKǍ̌OVSKÝ 1977b: 86) of the dialogue. This is illustrated by the fact that even though a certain mood has originated in the mental state of one of the participants in the dialogue, it often quickly takes hold of all the other participants and sets the tone of the entire emotional coloration of the dialogue, e.g. the doctor and the captain hinting at Maria's affair makes Woyzeck agitated and the audience alerted because of their mere insinuations. At these moments he inhabits an inaccessible world of his own, ridiculous to his interlocutors, a source of despair to himself, and a cause of compassion for the audience.

Another type of dialogue appears when the language of the exchange is not necessarily shared by the audience. In Woyzeck one special case is the miner's local dialect. 
To some of the audience it will seem to be subjectless discourse, while for others it might suggest an old tradition of macaronic poetry which mixes two or more languages (MUKAŘOVSKÝ 1977b: 87). The specialized jargon of the Doctor is reminiscent of the original macaronic poetry, mixing Latin with vernacular speech.

The dialogue can hint at a future action (Maria's affair) by using synonyms and homonyms (fire, glitter, the earrings that parallel the effect of her eyes and her erotic interest in the miner as the neighbor observed at the beginning). The material situation of the text, i.e. its context, is therefore omnipresent, if not always actually, then at least potentially, in the dialogue. In his play-script, Büchner himself introduces synonyms and homonyms that evoke different meanings of words like "nature," "seeing," and "eyes" (KARCEVSKIJ in VELTRUSKÝ 1977).

Rather than through cause and effect the events are set in motion by verbal and pictorial cues that hint at the relationships between the characters and motivate their action. There is also a delayed reaction to certain words, objects, and observations, that trigger or entail further actions, such as noticing the earrings; buying and using the knife; discarding the knife; and drowning.

A special case of non-verbal action is the silent setting of the table, which replaces the shaving of the Captain in the original text. What seems to be an intentional mundane activity, performed by Woyzeck and the puppeteers, turns into a danse macabre that frustrates the viewer's (and Woyzeck's) expectations. In fact, instead of the expected result, the sequence culminates in a black stain that marks the failure of the attempt to establish a certain order, and hints at Woyzeck's state of mind. The transformational blurring of the intentional activity into chaos foreshadows Maria's death (which is followed by a red stain) and eventually Woyzeck's own demise. Thus the stains are visual bridges between Woyzeck and Maria. The objects' primary function becomes obfuscated as they acquire a certain degree of independence. This shows that a "lifeless object may be perceived as the performing subject" (VELTRUSKÝ 1964: 84). The megaphone reduces the barker to a metonymy of his mouth, embodying his profession much as the stethoscope stands for the doctor.

Monologues by other characters can be performative speech acts in terms of giving orders, and very rarely do the characters directly react to each other. The exceptions are a few scattered exchanges between Woyzeck and Maria. They share several topics, such as their child, money, jealousy, and the Bible, even though they supposedly live in sin. Despite their presumably low social status they are both literate (Maria reads the Bible, Woyzeck quotes it at length). The rhino, like Woyzeck, is conditioned as a language user - he writes out the letter " $R$ " when commanded - and as a carrier of comic relief (for the audience, if not for the Captain and the Doctor).

The narrative of the poor orphan and his voyage into space is close to deixis am Phantasma and a folktale with no happy ending. Even though Woyzeck uses Andres as a confidant, his reactions are mostly confined to his accordion music. Similar to the miner, whose discourse is macaronic, the captain has his own speech, written in an idiom that forces the audience to read his hackneyed printed sentences, projected on the screen while he smokes. ("There's no hope that anything will be any different. ITS 
[sic] ALL SO BORING.") His speech also foregrounds the puppet-like behaviour of the captain that marks him as grotesque, a moniker that he otherwise applies to other characters: "These people make my head spin [...] Grotesque. Grotesque." Reminiscent of the Romantic poetics of the grotesque, the Captain foregrounds the distortion of his own language, of the text, and of his exchanges with the Doctor and Woyzeck.

The spoken and written text is supplemented by objects and projected images of objects, both professional and everyday, including a stethoscope, a spade, a crutch, the Bible as a source of moral values, the horseshoe (as the epitome of superstition allegedly evoking luck), and a pair of earrings (signifying Maria's infidelity). They are visible at once as material on the stage and as pictorial signs on screen. This doubling parallels the repetitions used by the Doctor and the Captain in their discourse, but it has a different function. In the discourse it is reductive, showing a limited vocabulary and worldview: the Doctor uses medical jargon, while the Captain's written notes consist of utterances void of meaning. The doubled objects, meanwhile, draw attention to themselves and their polysemic potential.

While Andres has his accordion as a means of expression, the miner employs the heavy spades to impress his onlookers. Both he and Woyzeck add dance to their repertoire of postures and movements as a non-verbal means of communication. Remarkable within puppet theatre, dance approximates human behavior and characters' respective intentions. Several dances structure the production. The first is the dance of the miner, who presents himself through a virtuosic solo display as a mobile object and an object of sexual desire for Maria. The next are the tête-à-tête erotic dances of Maria and the miner - the second of which is observed, surreptitiously, by Woyzeck. (In his eyes they are like animals performing a mating dance, more than objects but less than fully human.) The fourth is the dance between the miner and Maria's friend Katie. Woyzeck pronounces this an example of the meaningless and endless whirligig of sexual appetite that goes "on and on and on" and leads to his own solo dance. Woyzeck's final dance echoes the miner's opening dance: for the miner the dance was a display of masculine ostentation, for Woyzeck it is a display of frenzied desperation over his lost raison d'être.

\section{Spaces, represented and imaginary}

Veltruský added to Mukařovskýs discussion of dialogue the spatial component. This is important with respect to the title of Woyzeck on the Highveld, which locates the action in a specific geography in South Africa. It appears in Kentridge's sketches as a dilapidated landscape with buildings that are falling apart - an expressionist rendering of the highveld plateau around Johannesburg - and also as a space that opens up into Maria's dwelling and other locations.

Kentridge transformed his notion of the Freudian "[T]ummelplatz of the studio, which is a space of contestation, of play, of jousting, and of discovery" (KENTRIDGE 2017) into different spatial levels that the characters move on and that have their own 
semantic distinction. ${ }^{1}$ According to Karel Brušák the dramatic space is "the complex structure...built up of three constituents: the stage, the scene, and the action space." For Brušák, the action space consists "almost entirely of signs originated by the actors, emphasized or complemented by signs contributed by the sounds or lighting" (BRUŠÁK 1991: 146). In Kentridge's production, the action space consists of different positions of actors, lighting, and sounds on several spatial planes, thus creating a polyscenic spectacle. There are the interiors of Maria's and Woyzeck's rooms (home and dormitory, private and public) where the open door is at the intersection of twodimensional and three-dimensional space; there is the notion of the pub, as closed public space, which however, like Maria's room, is exposed through the windows. Indeed, the street as an open public space questions the privacy of actions and conversations. The captain and the doctor have their own idiosyncratic spaces that correspond to their respective jargons, full of objects denoting their professions and status. The "beautiful murder" takes place at a deserted lakeshore, but the lakeshore is not a comforting or Romantic depiction of nature.

In addition, the playing space of the stage is divided into five levels. The screen functions as a Tummelplatz on which people, animals, objects, and places move, morph, and merge. Beneath are three tiered levels at different heights on which the characters compete for the attention of the audience, which is asked to construct an order from this spatial polyphony. The barker establishes a proscenium by standing in front of and alongside the stage, inhabiting many of these spaces and assuming the position of a commentator and a director of the fictional world. In addition to the physical space, Woyzeck's monologues and the Captain's projected verbal diatribes gesture to what Brušák described as "imaginary space," where "action indispensable for the development of drama takes place," which "lies beyond the physical limitations of the stage and is only fully formed in the mind's eye of the spectator" (BRUŠÁK 1991: 145).

The various levels contribute to and spatialize the "episodic structure" that Kentridge considers filmic. Josef Svoboda saw film editing as a model for theatrical presentation, but he believed that "we cannot use rapid cutting techniques or enlarged details. We always have to work with the scene as a whole" (SVOBODA in GIESEKAM 2007: 52). Kentridge, however, creates a multidimensional model, bringing film editing into the space of the theatre.

\section{Characters, puppets, and objects}

Most of the characters in Woyzeck on the Highveld are unnamed stock types, except for Maria, Andres, and Woyzeck. Several characters are subordinate: Andres is Woyzeck's confidant and helper (PROPP 1968), whereas Maria's neighbor is the vessel of the vox populi who gives the conventional damning opinion of Maria. The Doctor and the Captain present themselves as self-undermining examples of white superiority:

1 For a psychoanalytic definition and exposition of Tummelplatz, see https://www.falter.at/the-viennareview/2011/beyond-freuds-playground. 
both try to impress each other with scientific gibberish. Because of their contrasting physical appearances (tall and thin, short and round) they evoke the stark oppositions of classical comedy duos from the commedia dell'arte through vaudeville.

Throughout the production, the characters of Woyzeck and Maria are multidimensional. They appear as complex subjects to the audience while being regarded as commodities by Woyzeck's white superiors. The Doctor and the Captain deny Woyzeck the ability to think and to act. They dismiss his dedication to the child and to Maria as well as his rich interior life. Woyzeck and Maria are characterized through their relationship to their baby, which fulfills several functions: he receives their emotions and reveals the link between them. Both relate to him as a fully-fledged human being. In so doing, they also demonstrate their capacity to express their feelings for each other and the child.

The production employs different stages of man and object as described by Veltruský, who has as the most extreme opposition the case "when the action falls to the zero level, [in which] the figure then becomes a part of the set" (VELTRUSKÝ 1964: 86). This applies, at times, to the character of Andres, who has different functions: as the musician, Woyzeck's interlocutor, and as a piece of scenery that indicates a place and sets a mood. The miner is an aesthetic object for Maria ("what a man!"), with his exposed chest and easy command of his spades (in contrast to Büchner's Maria, who fits the convention of a female object of sexual desire). Veltruský observes that "[i]t often seems that a given object in one situation is part of the set or costume and in the next becomes a prop" (VELTRUSKÝ 1964: 87). In the case of the miner, the situation is reversed: he first appears dancing with his spades, which then are subsumed into his costume.

The character of the puppet is unusual, in Handspring and other instances, in that it involves a blending between the puppet and the operator. As Jane Taylor notes, "the Woyzeck figure is being performed by Adrian, who is the world's angel in terms of puppetry manipulation and embodied sensibility; and Louis Seboko, who brings such an intensity to the character, was the secondary manipulator, but also spoke on Woyzeck's behalf. Our Woyzeck is in these two practices: in the hands of Adrian and in the sensibility of Louis's voice. So the kind of rupture in the heart of Woyzeck, the schizoid construction of the character of Woyzeck, is available in performance precisely because the body is an abstraction... a third being comes into existence in a kind of Trinitarian wonder that is neither Louis nor Adrian” (KOHLER et al. 2014: 32). The combination of rupture and active assembly of sometimes conflicting sensuous data exemplifies "hungry interpretation." Veltruský also helpfully calls our attention to the contradictions and confusions that generally attend puppet theatre. In "Puppetry and Acting," he comments, "In the puppet theatre the difference between the stage figure and the stage action and their dynamic mutual relations are brought out and also confused. They are brought out because there is a marked contradiction between the inanimate and the animate action imparted to it by manipulation and voice performance" (VELTRUSKÝ 1983: 70).

The inanimate object, action through manipulation, and the voice performance produce the complexity of Woyzeck as the stage figure. Initiated by Zich, the concept of 
the stage figure helps us to understand the relationship between characters, puppets, and objects. To Zich, "the stage figure is a formation of the physiological kind, the dramatic character a formation of the psychological kind" (ZICH in QUINN 1995: 72). Veltruský expanded the notion of the stage figure by distinguishing the "tripartite structure of the acting sign" (VELTRUSKÝ 1964): the actor, the character, and the stage figure. In the case of Woyzeck, we encounter a polyphonic acting sign because the puppeteers are visible, manipulating puppets across gender and race divisions and thus challenging the audience to create out of their respective actions the stage figure of the puppet Woyzeck. The spectators are confronted simultaneously with the manipulation of the object and the performers' active participation that goes beyond the mere mechanical and vocal auxiliary functions. As Veltruský notes they do not present only the character but also provide "information about the scene" (VELTRUSKÝ in QUINN 1995: 79). As a result, the puppeteers and the puppets foreground the subject-object relationship addressed by the doctor in Būchner's play. As Jane Taylor has proposed, Handspring's productions are particularly adept at querying "the relationship between 'beings' and 'things'" (TAYLOR 2009: 44).

In Woyzeck on the Highveld, Handspring discovered a "growing belief that animated figures could communicate great drama and express complex human emotion despite (and possibly because of) their artificiality" (TAYLOR 2009: 44). This belief coincides with Zich's wish to see a puppet theater performing real drama with bigger puppets. In contrast to Zich's claim regarding the conventions of puppet theatre, however, the Handspring puppets are mostly neither comic nor "uncanny" (ZICH 2015: 507). Some of them are grotesque, as mentioned earlier. The inherent distortion combined with the comic situations and characters counterpoints the illusion of represented reality.

The oscillation between inanimate objects and animated objects comes to the fore in the scene when Woyzeck gives away his worldly possessions at the end of the production. He both maps his biography and shows each of the objects, implicitly revealing his intention to part from his life. On the other hand, when Woyzeck speaks about the necklace around Maria's neck, he transforms the gruesome deed into a beautiful imaginary object. Thus he alludes to the "beautiful murder" that begins and ends the performance.

\section{Reception}

"The spectator never imagines that he is perceiving a reality and consequently it never occurs to him that what he perceives is not reality. He is aware that he perceives a reality different from his own reality. But he is also aware that he gradually construes this reality for himself." (BRUŠÁK 1991: 145)

This essay has sketched how William Kentridge and Handspring Puppet Company transformed the fictional world of the "most powerful" German drama (as Reinhardt called it) into the "as if" world of puppets, which is even more complex than the one 
defined by Keir Elam: "Dramatic worlds are hypothetical ('as if') constructs, that is, they are recognized by the audience as counterfactual (i.e. non-real) states of affairs but are embodied as if in progress in the actual here and now" (ELAM 2002: 89). The innovations of this production consist of both the constructions and transformations enacted by the creators and performers as well as the extraordinary acts of interpretation, destabilization, and reassembly that they demand from their audiences.

Woyzeck on the Highveld is not an adaptation, but rather a recycling of different European and African traditions and techniques, set in Africa. According to Veltruský, "Theatre is not another literary genre but another art form. It uses language as one of its materials, while for all the literary genres, including drama, language is the only material - though each organizes it in a different fashion" (VELTRUSKÝ 1977: 9). In Woyzeck on the Highveld, Kentridge and Handspring found a novel organization of theatrical materials, introducing filmic techniques into theatre and blending puppetry, cinema, music, language, and acting as a unique multimedia show. Puppets and people, spatial and temporal coordinates, lose their expected stability and become dynamic. The binary system of objects, people, puppets, music and sounds, and backdrops that do not serve merely as illustrations of the highveld is questioned and unsettles the audience. Kentridge's images de-automatize the convention of the static backdrop, as they move between film projections, animated actions and a three-dimensional set design, thus inviting the viewer to re-evaluate her/his expectations.

While the nature of race is never explicitly addressed in the spoken text, it determines the hierarchy of power within the action, while the puppeteers show art as a possibility of collaboration among differently raced artists. The barker and the puppeteers who literally run the show, most of whom are black, inhabit nonverbal South African postures and gestures, dancing and acting as embodiments of their characters on the level of action. As Kentridge has commented on the colonial charge of his 2017 production of Alban Berg's 1925 opera, Wozzeck: "It takes the private, rather than the [...] doctor or the captain, as the central figure. Its perspective is very much from the periphery" (FARAGO 2019). Even as Woyzeck on the Highveld evokes racial stereotyping, it upsets the equilibrium of preconceived race-based judgments in apartheid-era South Africa. While the two white characters, the Doctor and the Captain, claim their authority as an uncontested concept, they turn into comic figures. Woyzeck and Maria, meanwhile, acquire a tragic dimension.

Handspring and Kentridge challenge the audience to occupy an authorial position. As Basil Jones explains:

So the authorial audience is really what we talk about and in a way the moment when you take away the most usual semiotic, the semiotic of words, the spoken word or the written word, you force the audience into a much more interpretive space: the moment you have no words, you have to, as an audience member, work harder than if there are words. (KOHLER et al. 2014: 33) 
Woyzeck on the Highveld makes the audience hungry for interpretation - of sensuous data; of imagery; of genre; of political, social, and theatrical history. Semiotics at large and the semiotics of the Prague School provide tools to understand the polyphonous nature of this performance, which brought not only film into theatre and puppets to life, but also brought Woyzeck from Europe to Africa and from Africa to the world.

\section{Bibliography}

BALINT, Michael. 1994. Angstlust und Regression. Stuttgart: Klett-Cotta, 1994.

BOGATYREV, Petr. 1982. A contribution to the study of theatrical signs. In Peter Steiner (ed.). The Prague School: selected writings, 1929-1946. Austin: University of Texas Press, 1982: 55-63.

BRUŠÁK, Karel. 1991. Imaginary action space in drama. In Herta Schmid and Hedwig Král (eds.). Drama und Theater. Theorie - Methode - Geschichte. München: Otto Sagner, 1991: 144-62.

CARLSON, Marvin. 2001. The haunted stage: the theatre as memory machine. Ann Arbor: University of Michigan Press, 2001.

ELAM, Keir. 2002. The semiotics of theatre and drama. $2^{\text {nd }}$ ed. London and New York: Routledge, 2002.

GIESEKAM, Greg. 2007. Staging the screen: the use of film and video in theatre. Houndmills, Basingstoke and New York: Palgrave, 2007.

GROSZ, Georg. 1973. Theatrical drawings and watercolors. Cambridge: Busch-Reisinger Museum, 1973.

HONZL, Jindřich. 2016 [1943]. The hierarchy of dramatic devices. In David Drozd, Tomáš Kačer and Don Sparling (eds.). Theatre theory reader: Prague School writings. Prague: Karolinum Press, 2016: 157-64.

HUTCHEON, Linda. 2012. A theory of adaptation. Second edition. London: Routledge, 2012.

JAKOBSON, Roman. 1971. Studies in verbal art: texts in Czech and Slovak. Ann Arbor: Michigan Slavic Contributions No. 4, 1971.

JAKOBSON, Roman. 1987. An Open Letter from Roman Jakobson to Jiří Voskovec and Jan Werich on the Epistemology and Semantics of Fun. Stanford Slavic Studies 1 (1987): 155-162.

KEENE, Donald. 1998. Introduction to Four Major Plays of Chikamatsu. Translated by Donald Keene. New York: Columbia University Press, 1998.

KENTRIDGE, William and Jane TAYLOR. 2018. That Which We Do Not Remember. Sydney: Naomi Milgram Foundation, 2018.

KENTRIDGE, William. 2016. Interview with William Kentridge. In Terms of Performance, 2016. Available online at http://intermsofperformance.site/interviews/william-kentridge. Accessed on March 15, 2019.

KENTRIDGE, William. 2017. Tummelplatz, 2017. Available online at https://www.ivorypress. com/en/editorial/william-kentridge-tummelplatz/. Accessed on March 15, 2019.

KLETT, Renate. 1995. The Voice of Africa - The Handspring Puppet Company liest deutsche Klassiker anders: Woyzeck on the Highveld und Faustus in Africa. Theater heute 36 (1995): 9: $8-10$.

KOHLER, Adrian. 2018. Personal correspondence. November 28, 2018. 
KOHLER, Adrian, Basil JONES, Mervyn MILLAR, Jane TAYLOR and Nadia DAVIDS. 2014. "It's Very Tied to the Content of the Play." In Margherita Laera (ed.). Theatre and adaptation: return, rewrite, repeat. 2014: 23-40.

MATEJKA, Ladislav and Krystyna POMORSKA. 1978. Readings in Russian poetics: formalist and structuralist views. Ann Arbor: Michigan Slavic Publications, 1978.

MUKǍ̌OVSKÝ, Jan. 1932. An interview with B. Novak. Rozpravy Aventina 8 (1932): 226.

MUKǍ̌OVSKÝ, Jan. 1977a. On stage dialogue. In John Burbank and Peter Steiner (eds.). The word and verbal art. New Haven/London: Yale UP, 1977: 112-113.

MUKǍ̌OVSKÝ, Jan. 1977b. Two studies of dialogue. In John Burbank and Peter Steiner (eds.). The word and verbal art. New Haven/London: Yale UP, 1977: 81-115.

MUKAǨOVSKÝ, Jan. 1982. An attempt at a structural analysis of a dramatic figure. In Peter Steiner (ed.). The Prague School: selected writings, 1929-1946, trans. John Burbank et al. Austin: University of Texas Press, 1982: 171-177.

O'SULLIVAN, Michael. 2001. "Kentridge's Troubling Shades of Truth." The Washington Post (9. 3. 2001). Available online at https://www.washingtonpost.com/archive/lifestyle /2001/03/09/kentridges-troubling-shades of-truth/a6ce9675-32c9-4891-85ab-6a3f275e7bf4 /?utm_term=.2a98291e64fd. Accessed on March 10, 2019.

PISCATOR, Erwin. 1963. Das politische Theater (in collaboration with Felix Garbarra). Rowohlt: Reinbek, 1963.

PROPP, Vladimir Yakovlevich. 1968. A morphology of the folktale. Austin: University of Texas Press, 1968.

QUINN, Michael L. 1989. The Prague School concept of stage figure. In Gerald F. Carr and Irmengard Rauch (eds.). The Semiotic bridge. Trends from California. Berlin: Mouton de Gruyter, 1989: 75-85.

QUINN, Michael L. 1995. The semiotic stage. Prague School theater theory. New York: Peter Lang, 1995.

TAYLOR, Jane (ed.). 2009. Handspring puppet company. Parkwood: David Krut, 2009.

VELTRUSKÝ, Jiří. 1964. Man and Object in the Theater. In Paul L. Garvin (ed.). A Prague School reader on esthetics, literary structure, and style. Georgetown: Georgetown UP, 1964: 83-91.

VELTRUSKÝ, Jiří. 1977. Drama as literature. Lisse: The Peter de Ridder, 1977.

VELTRUSKÝ, Jiří. 1983. Puppetry and acting. Semiotica (guest-edited by Frank Proschan) 47 (1983): 1-4: 69-122.

VELTRUSKÝ, Jiří. 1987. Structure in folk theater: notes regarding Bogatyrev's book on Czech and Slovak folk theater. Poetics Today 8 (1987): 1: 141-161.

VODIČKA, Felix. 1982. The concretization of the literary work: problems of the reception of Neruda's Works (trans. John Burbank). In Peter Steiner (ed.). The Prague School: selected writings, 1929-1945. Austin: University of Texas Press, 1982: 103-134.

WESTIN, Monica and William KENTRIDGE. 2012. Handspring Puppet Company's Woyzeck on the Highveld. TimeOut Chicago (25. 9. 2012). Available online at https://www.timeout.com/ chicago/theater/handspring-puppet-companys-woyzeck-on-the-highveld. Accessed on March $1,2019$.

ZICH, Otakar. 2015. Puppet theatre. Theatralia 2 (2015): 2: 505-513.

This work can be used in accordance with the Creative Commons BY-NC-ND 4.0 International license terms and conditions (https:// creativecommons.org/licenses/by-nc-nd/4.0/legalcode). This does not apply to works or elements (such as images or photographs) that are used in the work under a contractual license or exception or limitation to relevant rights. 